\title{
Possible role of kallikrein in proteolysis of insulin-like growth factor binding proteins during the oestrous cycle and early pregnancy in pigs
}

\author{
R. D. Geisert ${ }^{1}$, C. S. Chamberlain ${ }^{1}$, K. A. Vonnahme ${ }^{1}$, \\ J. R. Malayer ${ }^{2}$ and L. J. Spicer ${ }^{1}$ \\ ${ }^{1}$ Department of Animal Science, Oklahoma Agricultural Experiment Station and \\ ${ }^{2}$ Department of Physiological Sciences, College of Veterinary Medicine, Oklahoma State \\ University, Stillwater, OK 74078, USA
}

During early pregnancy, pig conceptuses initiate the synthesis of oestrogens and on day 12 their trophoblastic membranes undergo a rapid expansion throughout the uterine horns. The insulin-like growth factor (IGF) system may be involved with conceptus development and steroidogenesis in pigs. Changes in uterine luminal IGF, insulin-like growth factor binding proteins (IGFBPs) and enzymatic activity for cleavage of IGFBPs during the oestrous cycle and early pregnancy were investigated. Uterine luminal content of IGF-I and IGF-II in uterine flushings from pigs on day 12 of pregnancy were two and three times greater, respectively, compared with uterine flushings collected from gilts during the oestrous cycle. Both IGF-I and -II content decreased on day 15 of gestation but content of IGF-II in uterine flushings remained three times

\section{Introduction}

Establishment of pregnancy in pigs relies on the physical alteration of conceptus morphology and the increase in conceptus steroidogenic enzymes necessary for synthesis of oestrogen during elongation of the trophoblast throughout the uterine horns (Geisert and Yelich, 1997). Days 11-12 of gestation in pigs clearly delineate the period of transition from a cyclic endometrium to a tissue receptive to placental attachment and maintenance of secretions for continued growth and development of conceptuses. The presence of elongating conceptuses within the uterine lumen of pigs correlates directly with increased uterine release of calcium (Geisert et al., 1982), endometrial proteins that include uteroferrin and retinol binding protein (Roberts and Bazer, 1988; Vallet et al., 1998), and enzymes such as cathepsins (Roberts et al., 1976; Geisert et al., 1997), tissue kallikrein (Vonnahme et al., 1999) and metalloproteinases (Menino et al., 1997). Uterine production and release of several growth factors is also associated temporally with conceptus

Email: geisert@okstate.edu greater than that of cyclic gilts. IGFBP-2 and -3 were the predominant binding proteins present in uterine flushings during days 0-10 of the oestrous cycle or day 10 of pregnancy. No IGFBPs were detected in the uterine flushings of either cyclic or pregnant pigs after day 10 by ligand blotting. Incubation of [ ${ }^{125}$ I]-labelled IGFBPs with various protease inhibitors indicated that cleavage of [ $\left.{ }^{125} \mathrm{I}\right]$-labelled IGFBP-2 and -3 in uterine flushings involved serine proteases such as tissue kallikrein and matrix metalloproteinases. The results of the present study indicate that an increase in tissue kallikrein activity on day 12 of the oestrous cycle and pregnancy in pigs can directly, or indirectly through activation of matrix metalloproteinases, cleave IGFBP-2 and -3, thus allowing uterine release of IGF-I and -II in the uterine lumen to stimulate conceptus development. elongation and steroidogenesis (see Geisert and Yelich, 1997). Endometrial synthesis of insulin-like growth factors (IGF) (Simmen et al., 1992; Green et al., 1995), heparin binding-epidermal growth factor (Brigstock et al., 1990), colony-stimulating factor 1 (Tuo et al., 1995), keratinocyte growth factor (Ka et al., 2000) and connective tissue growth factor (CTGF) (Harding et al., 1998) has been characterized in pig uterus.

IGF-I is one of the most studied and well-characterized growth factors in pig uterus. The greatest uterine luminal content of IGF-I occurs during the period of conceptus elongation (Simmen et al., 1992) and has been proposed to increase oestrogen synthesis through stimulation of conceptus aromatase gene expression (Green et al., 1995). Biological activity of IGF-I in tissues is regulated not only through its synthesis and release, but also the presence or absence of IGF-binding proteins (IGFBPs) can affect its availability to interact with IGF receptors (Rechler, 1993). Currently, six IGFBPs have been described in the regulation of IGF action (Rechler, 1993; Jones and Clemmons, 1995). Gene expression for IGFBP-2-6, but not IGFBP-1, has been detected in pig endometrium (Simmen et al., 1992; Song et al., 1996). IGFBP-2 and -3 are detected in uterine flushings by ligand and western blotting (Lee et al., 1998) and are the 
predominant IGFBPs in the uterine flushings of pregnant gilts before the period of conceptus elongation. However, there is a marked decline to complete absence of uterine IGFBP binding of radiolabelled IGF-II after the elongation of pig conceptuses on day 12 of gestation (Lee et al., 1998). These investigators proposed that protease activity was induced by the developing conceptuses; however, changes in IGFBPs were not evaluated in uterine flushings collected from contemporary females during the oestrous cycle. Lee et al. (1998) indicated that loss of IGFBP-3 in the uterine lumen during pregnancy was not the result of decreased gene expression, but rather of proteolysis. The IGFBP protease could be inhibited by EDTA and may involve a group of cation-dependent enzymes and possibly serine proteases.

Vonnahme et al. (1999) reported an increase in enzymatic activity of the serine protease kallikrein in the uterine lumen after day 10 of the pig oestrous cycle or pregnancy. Tissue kallikrein may function to assist in stabilization of the uterine epithelium extracellular matrix through the cleavage of inter- $\alpha$-trypsin heavy chain 4 $(\mathrm{I} \alpha \mathrm{lH} 4)$ and facilitate bradykinin release from kininogen (see Geisert and Yelich, 1997). The role of kallikrein in the release of bradykinin from kininogen, activation of growth factors and alteration of the extracellular matrix indicates that kallikreins may be involved with the various events of implantation in rats (Corthorn and Valdes, 1994; Chan et al., 1999). Uterine kallikrein activity is associated with oestrogen activation of implantation events in rats (Corthorn et al., 1997). As initiation of kallikrein activity in the uterine lumen parallels the time of elongation of pig conceptuses, oestrogen synthesis and proteolysis of uterine luminal IGFBPs, it is possible that tissue kallikrein could be involved with IGFBP cleavage during early pregnancy of pigs. The present study was undertaken to investigate the changes in uterine luminal content of IGF-I and -II, IGFBPs and IGFBP protease activity during the oestrous cycle and early pregnancy of gilts. The role of kallikrein in IGFBP proteolysis was evaluated though specific enzyme inhibitors to kallikrein and addition of the enzyme to uterine flushings containing IGFBPs.

\section{Materials and Methods}

\section{Animals}

Sexually mature crossbred gilts of similar ages (8-10 months) and body weight (100-130 kg) were checked twice a day for oestrous behaviour with intact boars. Onset of oestrous activity was considered day 0 of the oestrous cycle. Gilts assigned for mating were mated naturally with fertile boars at the onset of oestrus and $12 \mathrm{~h}$ later. Uterine flushings were collected from the uterine horns immediately after hysterectomy of cyclic gilts $(n=16)$ on days $0,5,10,12$ and 15 of the oestrous cycle and from pregnant gilts $(n=9)$ on days 10,12 or 15 of pregnancy. After surgical removal of the uterus as described by Gries et al. (1989), one uterine horn was isolated and flushed with $20 \mathrm{ml}$ PBS (pH 7.4). Uterine flushings were placed on ice until centrifugation (at $2500 \mathrm{~g}$ for $10 \mathrm{~min}, 4^{\circ} \mathrm{C}$ ) to remove cell debris and conceptus tissue from pregnant animals. The supernatant was divided into aliquots in sterile tubes and stored at $-80^{\circ} \mathrm{C}$ until thawed for analysis.

\section{Ligand blotting}

Uterine flushing samples were prepared for ligand blotting by concentrating $4 \mathrm{ml}$ sample using Centricon 10 concentrators (Amicon, Beverly, MA) with a cut-off molecular weight of 10000 . Protein content in concentrated uterine flushing samples was determined by the method of Lowry et al. (1951) using BSA as a standard. IGFBPs in uterine flushings were analysed by one-dimensional SDS-PAGE, as described by Echternkamp et al. (1994). In brief, $50 \mu \mathrm{g}$ uterine flushing protein was mixed with $21 \mu \mathrm{l}$ non-reducing denaturation buffer (BIORAD, Hercules, CA). In addition to uterine flushing samples, coloured molecular mass markers (Sigma Chemical Co, St Louis, MO) and $4 \mu \mathrm{l}$ bovine follicular fluid were used to identify band size and IGFBPs. The samples were denatured by heating at $100^{\circ} \mathrm{C}$ for $3 \mathrm{~min}$, centrifuged at $4657 \mathrm{~g}$ for $3 \mathrm{~min}$ and separated using 12\% (w/v) PAGE for about 18-20 h, at a constant current and variable voltage. After separation, proteins in the gels were transferred to nitrocellulose paper (Midwest Scientific, St Louis, MO) by electrophoresis for 2.5-3.0 h and ligandblotted overnight with [125I]-labelled IGF-II. Tris-buffered saline (TBS) with $0.1 \%(\mathrm{v} / \mathrm{v})$ Tween was used to wash the nitrocellulose blots. The nitrocellulose blots were dried and exposed to X-ray film at $-80^{\circ} \mathrm{C}$ for 14 days. The $X$-ray film was then developed and band intensity on autoradiographs was determined using scanning densitometry with Molecular Analyst (BIORAD).

\section{Analysis of proteolysis of IGFBP-2 and -3 in uterine flushings}

IGFBP-2 and -3 were iodinated by a modification of the chloramine-T method (Spicer et al., 1999). Recombinant human IGFBP-2 (31 kDa) was obtained from Austral Biologicals (San Ramon, CA) and recombinant human IGFBP-3 (47 kDa) was obtained from Upstate Biotechnology Inc (Lake Placid, NY). IGFBP-2 and -3 (2 $\mu \mathrm{g})$ were incubated independently with $1 \mathrm{mCi} \mathrm{Na}\left[{ }^{125} \mathrm{I}\right]$ (Amersham Pharmacia Biotech, Arlington Heights, IL) in the presence of $3.2 \mu \mathrm{g}$ chloramine- $\mathrm{T}$ for $30 \mathrm{~s}$ at $25^{\circ} \mathrm{C}$. The reaction was stopped by addition of $6 \mu \mathrm{g}$ sodium meta-bisulfate. [ $\left.{ }^{125} \mathrm{I}\right]$ labelled IGFBP-2 and -3 were purified from the reaction mixtures by Sephadex G-50 gel chromatography (Sigma Chemical Co).

Uterine flushings from day 10, 12 and 15 cyclic and pregnant gilts $(25 \mu \mathrm{g})$ were incubated at $37^{\circ} \mathrm{C}$ for $5 \mathrm{~h}$ with 60000 c.p.m. of either recombinant human [125I]-labelled IGFBP-2 or -3 mixed in $20 \mu \mathrm{l}$ Dulbecco's modified Eagle's medium-Ham's F12 medium (1:1; DMEM-F12). The various [125I]-labelled IGFBPs and their proteolytic fragments were 
separated by $12 \%(w / v)$ one-dimensional SDS-PAGE. Before gel electrophoresis, samples were boiled for $3 \mathrm{~min}$ to denature proteins and then added to the wells in the gel. Gels were dried onto filter paper with a vacuum and exposed to $\mathrm{X}$ ray film at $-80^{\circ} \mathrm{C}$ for $48 \mathrm{~h}$. Labelled IGFBP and proteolytic fragments were detected from the X-ray film. The resultant breakdown products or bands were determined using scanning densitometry with Molecular Analyst (BIORAD).

\section{Evaluation of protease inhibitors to IGFBP degradation}

Inhibition of uterine flushing protease activity to IGFBP was evaluated by pre-incubating (30 min) 60000 c.p.m. of either recombinant human [125I]-labelled IGFBP-2 or -3 in $30 \mu \mathrm{l}$ of DMEM-F12 medium with either $0.1 \mathrm{mmol}$ aprotinin $\mathrm{I}^{-1}, 1 \mathrm{mmol}$ leupeptin $\mathrm{I}^{-1}, 1 \mathrm{mmol}$ phenylmethanesulphonyl fluoride (PMSF) $\mathrm{I}^{-1}, 1 \mathrm{mmol} \mathrm{E}-64 \mathrm{I}^{-1}$ (Boehringer Mannheim, Indianapolis, IN), $5 \mathrm{mmol}$ 1,10-phenanthroline $\mathrm{I}^{-1}, 1 \mathrm{mmol}$ deoxycycline $\mathrm{I}^{-1}, 1 \mathrm{mmol}$ cyclohexylacetyl-

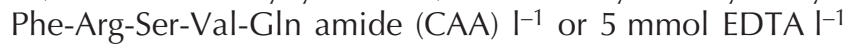
(Sigma Chemical Co). After pre-incubation of protease inhibitors, $25 \mu \mathrm{g}$ protein from a pool of day 12 and day 15 cyclic and pregnant uterine flushings was added, the tubes were gently vortexed and the sample mixture was incubated at $37^{\circ} \mathrm{C}$ for $5 \mathrm{~h}$. Addition of PBS containing $25 \mu \mathrm{g}$ BSA and $25 \mu \mathrm{g}$ protein from a pool of day 10 cyclic and pregnant uterine flushings served as a control to monitor IGFBP breakdown during incubation. Samples were separated by $12 \%(\mathrm{w} / \mathrm{v})$ one-dimensional SDS-PAGE and subjected to autoradiography as described earlier.

Analysis of kallikrein, tissue plasminogen activator and matrix metalloproteinase 3 enzyme activity on IGFBP-2 and -3

Direct proteolysis of IGFBPs was evaluated by incubating 60000 c.p.m. of either recombinant human [125I]-labelled IGFBP-2 or -3 in $30 \mu$ l of DMEM-F12 medium with $3 \mu \mathrm{g}$ of either pig kallikrein (pig pancreas), tissue plasminogen activator (Calbiochem-Novabiochem Corp, La Jolla, CA) or matrix metalloproteinase 3 (MMP-3) (Sigma Chemical Co) in the presence or absence of $25 \mu \mathrm{g}$ protein from a pool of day 10 pregnant and cyclic uterine flushings. As a positive control, a pooled sample of day 12 and 15 concentrated uterine flushing protein $(25 \mu \mathrm{g})$ was incubated with either recombinant human ${ }^{125}$ I]-labelled IGFBP-2 or -3 . Samples were incubated at $37^{\circ} \mathrm{C}$ for $5 \mathrm{~h}$, followed by onedimensional $12 \%(\mathrm{w} / \mathrm{v})$ SDS-PAGE and autoradiography as described earlier.

\section{Inhibition of uterine IGFBP proteolysis with inhibitors to kallikrein and MMPS}

Protein $(25 \mu \mathrm{g})$ from a pooled sample of day 10 cyclic gilts in $30 \mu \mathrm{l}$ DMEM-F12 media was co-incubated with $12.5 \mu \mathrm{g}$ protein from day 15 uterine flushings at $37^{\circ} \mathrm{C}$ for $5 \mathrm{~h}$ in the presence or absence of $2 \mathrm{mmol}$ CAA (kallikrein inhibitor), $1 \mathrm{mmol}$ deoxycycline (MMP inhibitor) or CAA plus deoxycycline. Samples of protein from day 10 and day 15 uterine flushings were incubated alone and served as controls. After incubation, samples were run on a onedimensional $12 \%(\mathrm{w} / \mathrm{v})$ SDS-PAGE and ligand blotted with [125I]-labelled IGF-II as described earlier.

\section{IGF radioimmunoassay of uterine flushings}

Uterine content of IGFs in cyclic and pregnant females was determined in uterine flushings collected on days 10 , 12 and 15. Concentration of IGF-I in of uterine flushings was determined in a single assay by radioimmunoassay after acid-ethanol extraction $\left(16 \mathrm{~h}\right.$ at $\left.4^{\circ} \mathrm{C}\right)$ as described by Echternkamp et al. (1990). The intra-assay coefficient of variation was $9.0 \%$. Concentration of IGF-II in uterine flushings was determined in a single assay by radioimmunoassay as described by Spicer et al. (1995). The intra-assay coefficient of variation was $9.2 \%$.

\section{Statistical analysis}

Data were analysed statistically by least squares ANOVA using the General Linear Models procedure of SAS (SAS, 1988). The statistical model used to analyse uterine flushing enzymatic activity to IGFBP cleavage, and IGF-I and -II content in uterine flushings included effects of day, reproductive status and day by reproductive status interaction.

\section{Results}

IGFBPs in uterine flushings during the oestrous cycle and early pregnancy

Presence of IGFBPs in the uterine lumen of cyclic and pregnant gilts as evaluated through ligand blot analyses with [125I]-labelled IGF-II is shown (Fig. 1). An intense IGFBP band at approximately $34 \mathrm{kDa}$, putative IGFBP-2 (Lee et al., 1998), was present at oestrus (day 0) with detection of two lighter bands between $40 \mathrm{kDa}$ and $46 \mathrm{kDa}$. The major band of IGFBP-2 was absent in day 5 uterine flushings from cyclic gilts with only faint detection of the two bands $\geqslant 40 \mathrm{kDa}$. The two bands from $40-46 \mathrm{kDa}$, which are variants of IGFBP-3 in pig serum (Lee et al., 1998), were the major IGFBP present in uterine flushings of both cyclic and pregnant gilts. However, bands of 34 and $30 \mathrm{kDa}$ were also detectable in uterine flushings from both pregnant and cyclic gilts with a faint band at $26 \mathrm{kDa}$. With the exception of one day 12 uterine flushing from a cyclic gilt, no discrete bands were present in either cyclic or pregnant uterine flushings collected on days 12 and 15. A faint band of $34 \mathrm{kDa}$ was visible on day 15 of the oestrous cycle which was absent in uterine flushings from pregnant pigs.

\section{Enzymatic cleavage of [ [ ${ }^{125}$ I]-labelled IGFBP-2 and -3 by uterine flushings from cyclic and pregnant gilts}

After $5 \mathrm{~h}$ incubation with uterine flushings from day 10 cyclic or pregnant gilts, neither recombinant human 


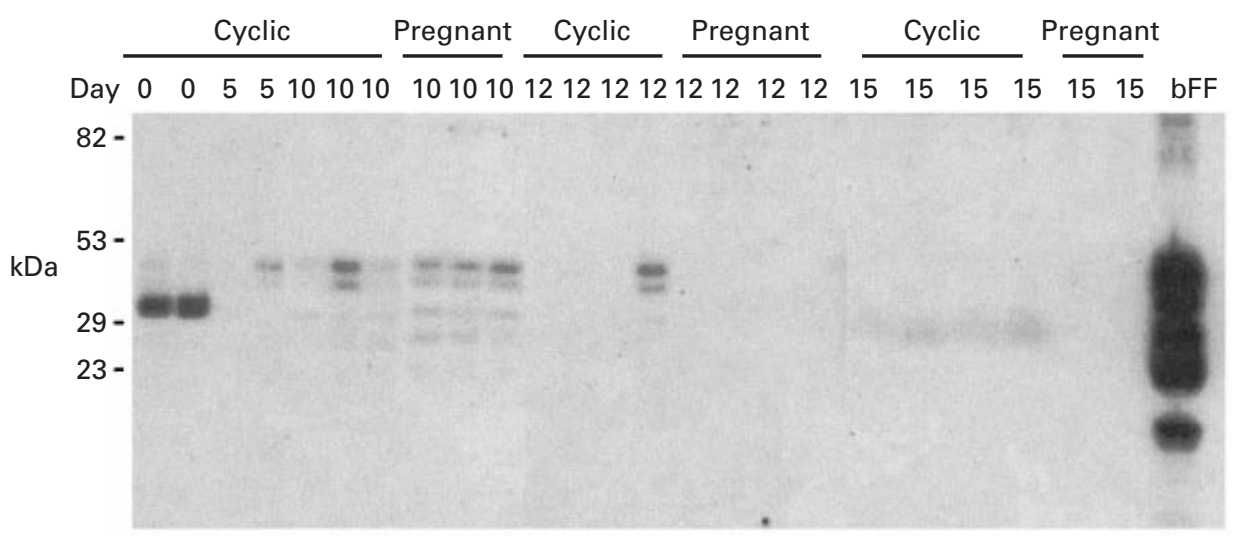

Fig. 1. Ligand binding of [ ${ }^{125}$ I]-labelled IGF-II (insulin-like growth factor II) to insulin-like growth factor binding proteins (IGFBPs) in concentrated uterine flushings of individual gilts collected on selected days of the oestrous cycle (days 0, 5, 10, 12 and 15; cyclic) and early pregnancy (days 10, 12 and 15; pregnant). Pre-stained coloured markers were used to define the sizes of the bands and bovine follicular fluid (bFF) served as a positive control, as well as a marker to identify the various IGFBPs.

[125I]-labelled IGFBP-2 (Fig. 2a) nor [125I]-labelled IGFBP-3 (Fig. 2b) showed significant enzymatic cleavage compared with incubation of the $\left[{ }^{125} \mathrm{I}\right]$-labelled-IGFBP alone. However, with the exception of one day 12 cyclic gilt, incubation of day 12 and 15 concentrated uterine flushing protein from cyclic and pregnant gilts with [125I]-labelled IGFBP-2 (Fig. 2a) or -3 (Fig. 2b) resulted in cleavage $(P<0.01)$ of the IGFBPs into two distinct bands of approximately 18 and 12 kDa for IGFBP-2, and 25 and 16 kDa for IGFBP-3.

\section{Prevention of cleavage of human recombinant IGFBP-2} and -3 by kallikrein and MMP inhibitors

Enzymatic activity in the pooled sample of day 12 and 15 cyclic and pregnant uterine flushings to the recombinant human [ $\left.{ }^{125} \mathrm{I}\right]$-labelled IGFBP-3 was suppressed or inhibited by PMSF, 1,10-phenanthroline, deoxycycline, EDTA and CAA (Fig. 3). However, only deoxycycline was able to decrease proteolysis of [125l]-labelled IGFBP-2 after a $5 \mathrm{~h}$ incubation with the concentrated uterine flushing protein (Fig. 4). Presence of $5 \mathrm{mmol}$ EDTA did not inhibit uterine flushing enzyme activity for human [ $\left.{ }^{125} \mathrm{I}\right]$-labelled IGFBP-2 (Fig. 4). Although pre-incubation of $0.4 \mathrm{mmol} C A A$, which is a specific kallikrein inhibitor, did not inhibit uterine flushing enzyme cleavage of human [ ${ }^{125}$ I]-labelled IGFBP-2, decreasing the amount of uterine flushing protein and increasing the amount of kallikrein inhibitor (CAA) to $2 \mathrm{mmol} \mathrm{I}^{-1}$ decreased proteolysis with complete inhibition at $5 \mathrm{mmol} \mathrm{I}^{-1}$ (Fig. 5).

\section{Blocking of cleavage of uterine flushing IGFBPs by kallikrein and MMP inhibitors}

Ligand blotting of a pool of day 10 uterine flushings with [125I]-labelled IGF-II detected the presence of the predominant bands of IGFBP-3 and a faint band of IGFBP-2
(Fig. 6). Co-incubation of the day 10 uterine flushings with day 15 uterine flushings resulted in complete loss of the IGFBP bands. Loss of the IGFBPs in the day 10 uterine flushings mixed with day 15 uterine flushings protein was inhibited with either specific kallikrein inhibitor (CAA) or deoxycycline.

\section{Cleavage of recombinant human IGFBP-2 and -3 with kallikrein and MMP-3}

Incubation of recombinant human [ $\left.{ }^{125} \mathrm{I}\right]$-labelled IGFBP2 with a pool of day 12 and day 15 uterine flushing protein resulted in complete cleavage of the IGFBP-2 (Fig. 7a). Addition of pig pancreatic kallikrein to the culture medium resulted in proteolysis similar to that of the day 12 and 15 uterine flushing protein. Proteolysis of [125I]-labelled IGFBP-2 was also observed with coculture of tissue plasminogen activator and MMP-3. Although the molecular masses of cleavage products were similar among the three enzymes, the profiles of cleavage products were different. Only kallikrein effectively cleaved [ ${ }^{125}$ I]-labelled IGFBP-3 (Fig. 7b). Both tissue plasminogen activator and MMP-3 had little effect on proteolysis of IGFBP-3.

Presence of day 10 uterine flushing protein in culture media greatly decreased the cleavage of [125I]-labelled IGFBP-2 by kallikrein. A major kallikrein cleavage product of approximately $22 \mathrm{kDa}$, similar to culture of MMP-3 alone with [125I]-labelled IGFBP-2, was present when IGFBP-2 was cultured with day 10 uterine flushings but was not detected in the absence of uterine flushings (Fig. 7a). Day 10 uterine flushing protein suppressed MMP-3 cleavage of IGFBP-2 with no proteolysis observed with tissue plasminogen activator. Presence of day 10 uterine flushing protein inhibited proteolysis of [125I]-labelled IGFBP-3 by all three enzymes used in the experiment (Fig. 7b). 

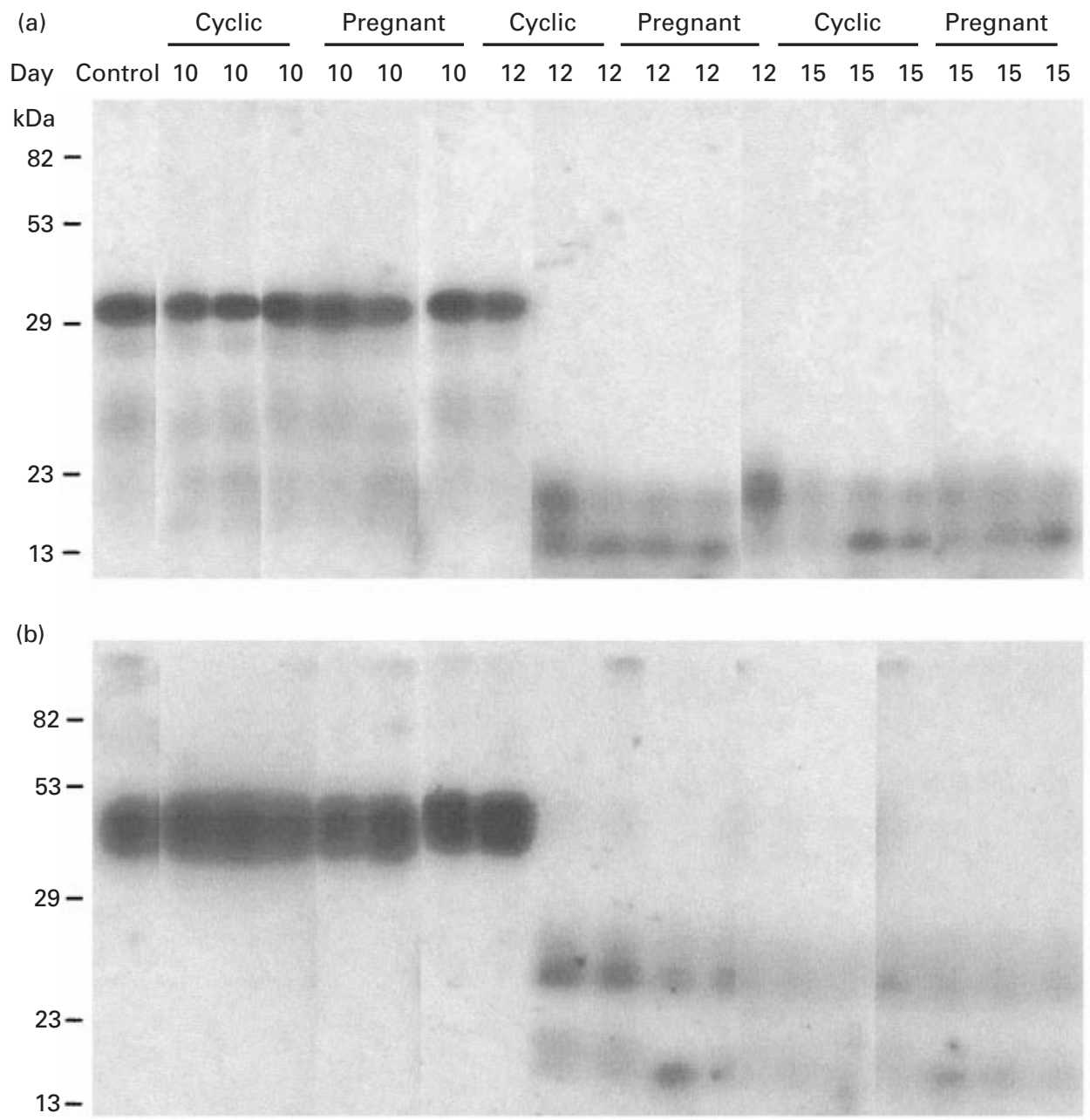

Fig. 2. Proteolysis of (a) recombinant human [125I]-labelled insulin-like growth factor binding protein 2 (IGFBP-2) and (b) recombinant human [ ${ }^{125}$ I]-labelled IGFBP-3 by individual gilt uterine flushings collected on days 10,12 and 15 of the oestrous cycle (cyclic) and pregnancy (pregnant). Concentrated uterine flushing protein $(25 \mu \mathrm{g})$ was incubated with recombinant human [125 I]labelled IGFBP-2 or IGFBP-3 at $37^{\circ} \mathrm{C}$ for $5 \mathrm{~h}$. Control: incubation of recombinant human [125I]-labelled IGFBP-2 with BSA.

\section{IGF-I and -II content in the uterine flushings of cyclic and pregnant gilts}

Total content of IGF-I in uterine flushings was affected by status $(P<0.01)$ and day $(P<0.001)$. Uterine content of IGF-I was similar in cyclic and pregnant gilts on day 10 , but there was a two times increase $(P<0.01)$ in IGF-I content in the uterine flushings of pregnant gilts on day 12 (Fig. 8a). On day 15 , total IGF-I content in uterine flushings of pregnant gilts decreased eight times and was not significantly different from that of cyclic gilts.

Uterine IGF-II content was approximately five times lower than IGF-I content. A significant status by day interaction $(P<0.01)$ was detected for IGF-II content in uterine flushings of cyclic and pregnant gilts (Fig. 8b). IGF-II content in uterine flushings decreased from day 10 to day 15 of the oestrous cycle but this decrease was not significant. In contrast to cyclic gilts, IGF-II content increased almost three times $(P<0.01)$ in uterine flushings by day 12 of pregnancy. Although the total content of IGF-II decreased in uterine flushings of pregnant gilts on day 15 , uterine flushing IGF-II content remained three times greater than that of cyclic gilts.

\section{Discussion}

Establishment of epitheliochorial pregnancy in pigs is dependent on rapid conceptus expansion throughout the uterine horns and release of oestrogen (Geisert and Yelich, 1997). Clearly, these alterations in conceptus development and steroidogenesis are associated temporally with a marked transition of the secretions within the uterine lumen. Of the many growth factors present, endometrial 


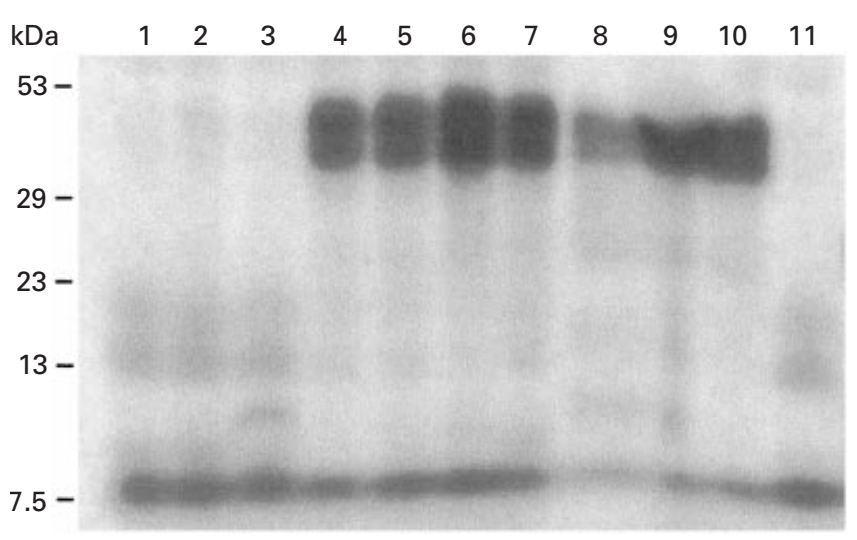

Fig. 3. Protease activity of a pooled day 12 and day 15 concentrated sample of uterine flushing protein $(25 \mu \mathrm{g})$ incubated at $37^{\circ} \mathrm{C}$ for $5 \mathrm{~h}$ with recombinant human $\left[{ }^{125} \mathrm{I}\right]$-labelled insulin-like growth factor binding protein 3 (IGFBP-3) in the presence of either $1 \mathrm{mmol} \mathrm{E}-64 \mathrm{I}^{-1}$ (lane 1), $1 \mathrm{mmol}$ leupeptin $\mathrm{I}^{-1}$ (lane 2), $0.1 \mathrm{mmol}$ aprotinin $\mathrm{I}^{-1}$ (lane 3), $1 \mathrm{mmol}$ phenylmethane-sulphonyl fluoride $\mathrm{I}^{-1}$ (lane 4), $5 \mathrm{mmol}$ 1,10-phenanthroline $\mathrm{I}^{-1}$ (lane 5), $1 \mathrm{mmol}$ deoxycycline $\mathrm{I}^{-1}$ (lane 6), $5 \mathrm{mmol}^{\mathrm{EDTA} \mathrm{I}}{ }^{-1}$ (lane 7) or $0.4 \mathrm{mmo}$ cyclohexylacetyl-Phe-Arg-Ser-Val-GIn amide I $^{-1}$ (lane 8). Controls for the incubation were recombinant human [125]]-labelled IGFBP3 in media alone (lane 9), BSA (lane 10) or with the pooled day 12 and 15 concentrated sample of uterine flushing protein (lane 11).

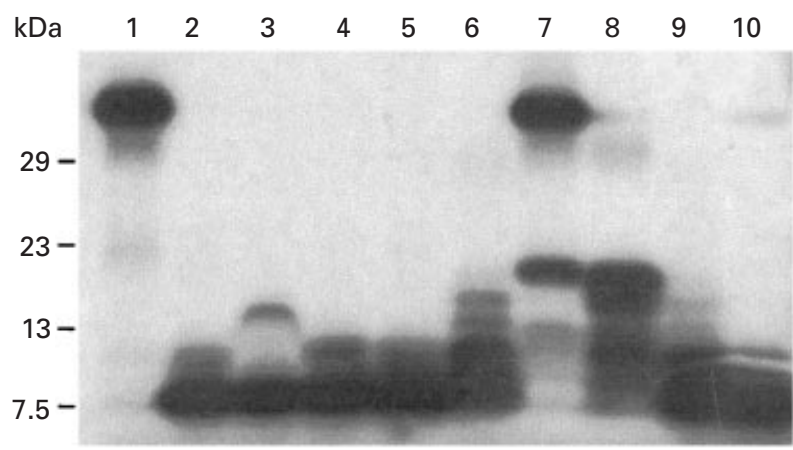

Fig. 4. Protease activity of a pooled day 12 and 15 concentrated sample of uterine flushing protein $(25 \mu \mathrm{g})$ incubated at $37^{\circ} \mathrm{C}$ for $5 \mathrm{~h}$ with recombinant human [125I]-labelled insulin-like growth factor binding protein 2 (IGFBP-2) in the presence of either $1 \mathrm{mmol} \mathrm{E}-64$ $\mathrm{I}^{-1}$ (lane 2), $0.1 \mathrm{mmol}$ aprotinin $\mathrm{I}^{-1}$ (lane 3 ), $1 \mathrm{mmol}$ leupeptin $\mathrm{I}^{-1}$ (lane 4), $1 \mathrm{mmol}$ phenylmethane-sulphonyl fluoride $\mathrm{I}^{-1}$ (lane 5), 5 mmol 1,10-phenanthroline $\mathrm{I}^{-1}$ (lane 6), $1 \mathrm{mmol}$ deoxycycline $\mathrm{I}^{-1}$

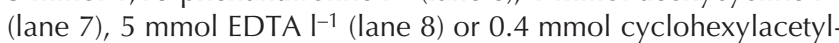
Phe-Arg-Ser-Val-GIn amide I $^{-1}$ (lane 9). Controls for the incubation were recombinant human [ ${ }^{125}$ I]-labelled IGFBP-2 in presence of BSA (lane 1) or with the pooled day 12 and 15 concentrated sample of uterine flushing protein (lane 10).

synthesis and release of IGF-I has been demonstrated to be tightly coupled to the time of conceptus elongation and oestrogen synthesis (Simmen et al., 1995).

Uterine luminal content of IGF-I increases as pig conceptuses undergo the transition from spherical to

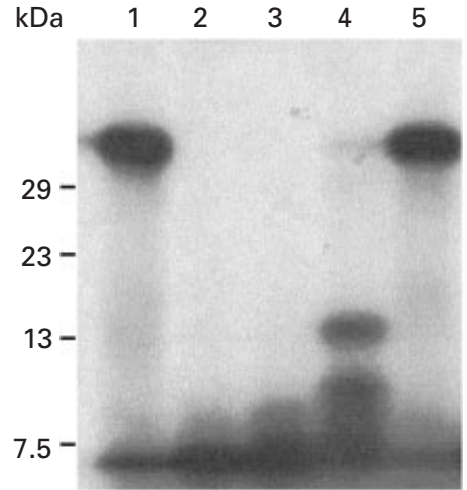

Fig. 5. Protease activity of a pooled day 12 and 15 concentrated sample of uterine flushing protein $(12.5 \mu \mathrm{g})$ incubated at $37^{\circ} \mathrm{C}$ for $5 \mathrm{~h}$ with recombinant human [125 I]-labelled insulin-like growth factor binding protein 2 (IGFBP-2) in the presence of 1 (lane 3), 2 (lane 4) and 5 (lane 5) mmol cyclohexylacetyl-Phe-Arg-Ser-ValGln amide ${ }^{-1}$. Controls for incubation were recombinant human [125I]-labelled IGFBP-2 with BSA (lane 1) and the pooled day 12 and 15 concentrated sample of uterine flushing protein (lane 2).

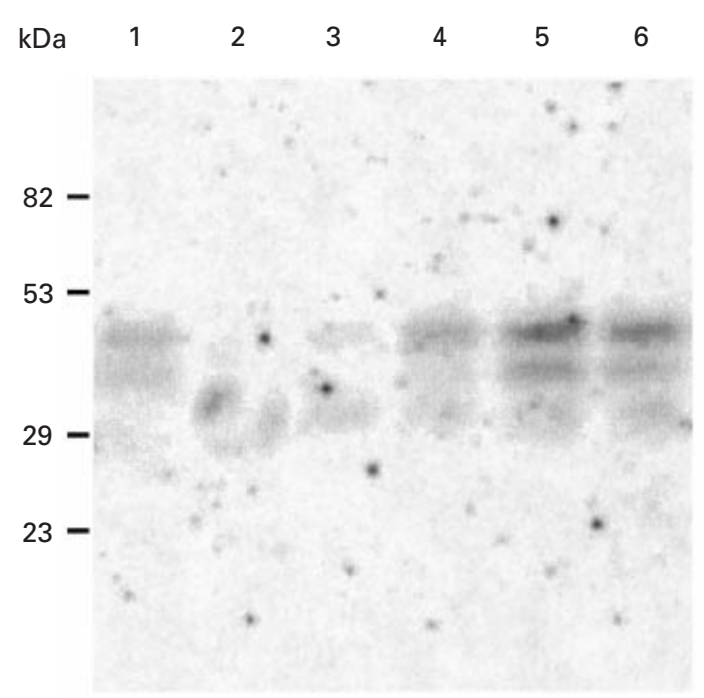

Fig. 6. Ligand binding of [ $\left.{ }^{125} \mathrm{I}\right]$-labelled IGF-II (insulin-like growth factor II) to insulin-like growth factor binding proteins (IGFBPs) in a day 10 pool of concentrated $(100 \mu \mathrm{g})$ uterine flushings (lane 1$)$, a pool of day 12 and 15 uterine flushings (lane 2) and after coincubation of day 10 uterine flushing protein with day 12 and 15 uterine flushings $(12.5 \mu \mathrm{g})$ in the absence (lane 3$)$ or presence (lane 4) of $2 \mathrm{mmol}$ cyclohexylacetyl-Phe-Arg-Ser-Val-GIn amide (CAA) $\mathrm{I}^{-1}, 1 \mathrm{mmol}$ deoxycycline $\mathrm{I}^{-1}$ (lane 5) or CAA plus deoxycycline (lane 6).

filamentous morphology between day 11 and day 12 of pregnancy (Letcher et al., 1989; Ko et al., 1994; Green et al., 1995). An increase in conceptus oestrogen synthesis occurs after conceptuses reach the 5-6 mm spherical stage of development (Geisert and Yelich, 1997). Green et al. 

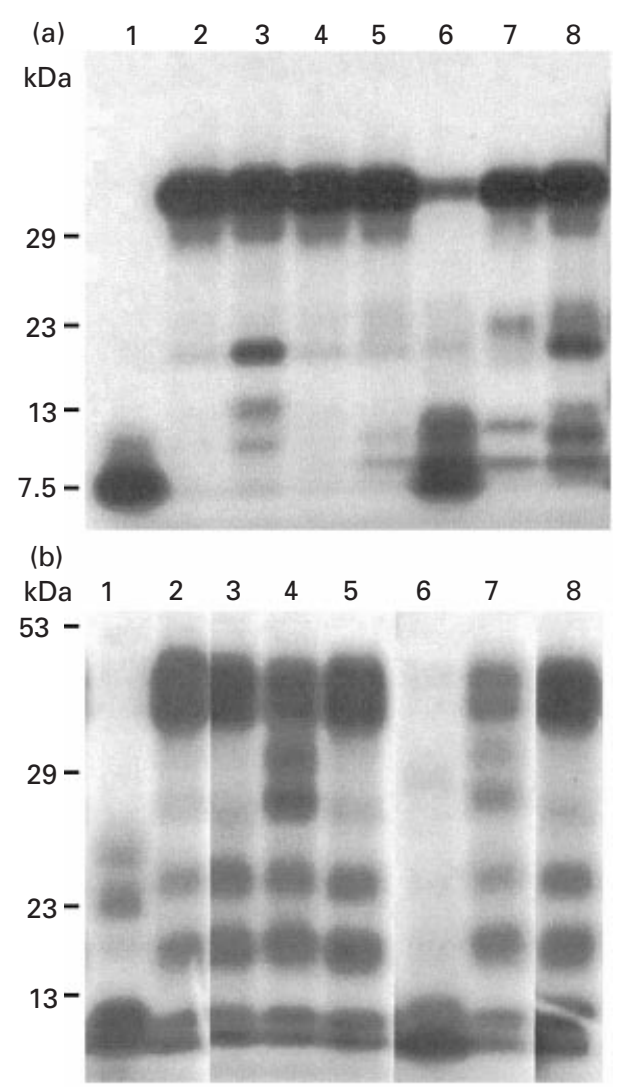

Fig. 7. Proteolysis of (a) recombinant human [125|]-labelled insulin-like growth factor binding protein 2 (IGFBP-2) and (b) recombinant human [ ${ }^{125} \mathrm{I}$-labelled IGFBP-3 after incubation at $37^{\circ} \mathrm{C}$ for $5 \mathrm{~h}$ with $3 \mu \mathrm{g}$ of either pig pancreatic kallikrein (lanes 3 and 6), tissue plasminogen activator (lanes 4 and 7) or matrix metalloproteinase 3 (MMP-3) (lanes 5 and 8) in the presence (lanes 3-5) or absence (lanes 6-8) of a day 10 pool of concentrated uterine flushing protein. Incubation of a concentrated day 12 and 15 pooled uterine flushing sample (lane 1 ) and the pooled day 10 uterine flushing protein (lane 2) served as a positive and negative control, respectively.

(1995) suggested that the close association of conceptus development and the increase in luminal IGF-I content during early pregnancy might form a positive conceptusendometrial loop whereby oestrogen synthesis by the conceptus stimulates luminal release of endometrial IGF-I that enhances gene expression for oestrogen synthesis. In vitro, IGF-I increases P450 aromatase gene expression of filamentous conceptuses (Green et al., 1995). The two times increase in uterine luminal IGF-I content on day 12 of pregnancy observed in the present study is consistent with previous reports (Letcher et al., 1989; Ko et al., 1994; Green et al., 1995). In addition, a coincident six times increase in uterine luminal IGF-II content was observed. The increase in luminal IGF-I and -II content on day 12 of pregnancy appears to be induced by the conceptuses, as the increase in IGF-I did not occur in contemporary cyclic females. Increase in IGF-I content is temporary, as concentrations
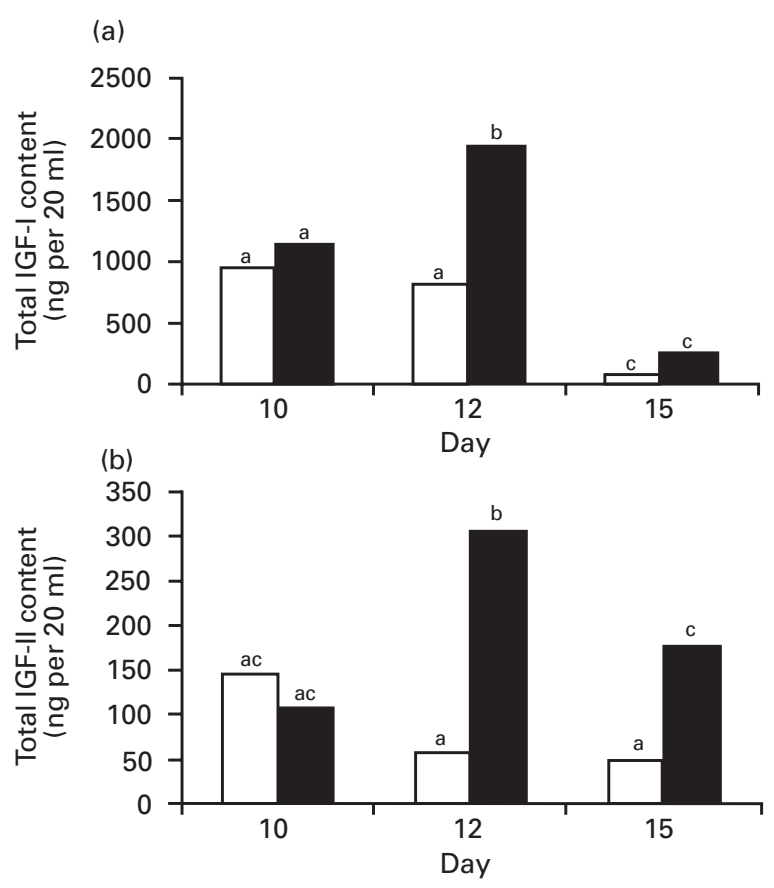

Fig. 8. Total (a) insulin-like growth factor I (IGF-I) and (b) IGF-II content in uterine flushings from cyclic $(\square)$ and pregnant $(\mathbf{\square})$ gilts. A status $(P<0.01)$ and day $(P<0.001)$ effect were detected for total content of IGF-I in uterine flushings and a status by day effect $(P<0.01)$ was detected for total IGF-II content. Values are least squares means. abc Columns without a common letter are significantly different $(P<0.01$ for IGF-I and $P<0.05$ for IGF-II).

decrease on day 15 and are not different from the lower amounts in the uterine lumen of cyclic gilts as has been reported previously (Letcher et al., 1989). In contrast, although uterine luminal IGF-II content decreases on day 15 of pregnancy, the concentrations remain significantly greater than those of cyclic females. The presence of oestrogen receptors in the uterine surface and glandular epithelium on day 12 (Geisert et al., 1993), coupled with the close association for increased uterine luminal IGF-I and -II during conceptus elongation and oestrogen release (Green et al., 1995; present study), support a positive feedback loop system for uterine IGF and conceptus oestrogen secretion that was proposed by Green et al. (1995).

The biological actions of IGFs can be regulated through the presence or absence of IGFBPs (Rechler, 1993). Lee et al. (1998) detected the presence of IGFBP-2, -3 and an unidentified $26 \mathrm{kDa}$ IGFBP in uterine flushings obtained between day 10 and day 11 of pregnancy. In the present study, IGFBP-3 was the predominant IGFBP present in the uterine flushings from both pregnant and cyclic gilts. Changes in the predominance of IGFBP-2 and -3 occurred during the oestrous cycle. During the oestrous cycle, IGFBP-2 was clearly the most abundant binding protein during oestrus, declining on day 5 with IGFBP-3 becoming 
the more dominant IGFBP by day 5 through to day 10 . Ligand blotting did not detect any of the IGFBPs on day 12 of the oestrous cycle or early pregnancy. Lee et al. (1998) indicated that the loss of IGFBPs was associated with transition of the conceptuses during elongation of the trophoblast and oestrogen release. These authors suggested that the elongating conceptuses were responsible for inducing IGFBP protease activity, which would then allow an increase in the bioavailability of IGF to the conceptuses and uterine tissue. The results of the present study indicate that the loss of the uterine luminal IGFBPs cannot be attributed solely to the presence of conceptuses. Although elongating pig conceptuses secrete plasminogen activator (Fazleabas et al., 1983) and MMPs (Menino et al., 1997) that function to cleave IGFBPs, the IGFBPs were also clearly absent from uterine flushings of day 12 cyclic gilts. The results of the present study indicate that the timing for proteolysis of uterine IGFBPs may be influenced by progesterone stimulation as has been proposed for secretion of many pig uterine proteins and enzymes (Trout et al., 1992; Roberts et al., 1993; Geisert et al., 1997). Alteration in uterine protein secretion in pigs follows downregulation of surface and glandular epithelial progesterone receptors on day 10 of either the oestrous cycle or pregnancy (Geisert et al., 1994).

Lee et al. (1998) demonstrated that loss of IGFBP-3 in day 12 uterine flushings is not the result of decreased endometrial gene expression but rather increased protease activity in the uterine lumen. Proteolysis was inhibited with EDTA but the inhibition was not zinc ion-dependent, indicating that metal-dependent MMPs may not be involved. Partial inhibition of protease activity with aprotinin indicated that a serine protease might be involved with IGFBP degradation. In the present study, protease activity of uterine flushings to human recombinant IGFBP-3 was suppressed or inhibited by PMSF (serine protease inhibitor) and CAA (a specific inhibitor to the serine protease kallikrein). Differences in results from enzyme inhibitors with the present study may be related to the shorter ( $5 \mathrm{~h}$ ) incubation period used in the present study. Shorter incubation periods allowed suppression of proteolysis to be evaluated before complete degradation of the IGFBPs had occurred. Cleavage of human recombinant IGFBP-2 by uterine flushings was also suppressed with the kallikrein specific inhibitor. The kallikrein inhibitor was also effective in suppressing day 12 and 15 uterine flushing protein cleavage of IGFBPs in day 10 uterine flushings. Human recombinant IGFBP-2 and -3 , which have $>75 \%$ amino acid homology to pig IGFBP-2 and -3, were cleaved with pig pancreatic kallikrein, indicating that kallikrein can have a direct proteolytic effect on both IGFBPs. Members of the kallikrein gene family degrade IGFBP-2 (Elmlinger et al., 1999) and -3 (Cohen et al., 1992). Use of pancreatic kallikrein demonstrated that a source of pig kallikrein is proteolytic to IGFBP-2 and -3. Kallikrein belongs to a multigene family of serine proteases, which consists of approximately 15 related genes in rats (Gauthier et al.,
1992) and humans (Yousef et al., 2000). The kallikrein family has diverse substrate specificity and variable sensitivities to inhibitors such as aprotinin (Gauthier et al., 1992); however, the genes have extensive homology to each other and among species (Clements, 1997). Although the specific tissue kallikrein in the uterus of pigs was not isolated in the present study, the results indicate clearly that kallikrein is a serine protease involved in IGFBP proteolysis.

Uterine secretion of active tissue kallikrein is an attractive model that fits the biological changes that occur in IGFBPs during the oestrous cycle and early pregnancy. Vonnahme et al. (1999) indicated that kallikrein activity in pig uterus increases on day 12 of the oestrous cycle and is also closely associated with transition of the conceptuses to filamentous morphology, which is consistent with the loss of the IGFBPs in the study of Lee et al. (1998). Kallikrein is most noted for its function in the release of bradykinin from kininogen (Bhoola et al., 1992) and has been implicated in the events of implantation in rats (Corthorn and Valdes, 1994; Chan et al., 1999; Murone et al., 1999). Uterine bradykinin increases during days 12-18 of pregnancy but not during the oestrous cycle in pigs (M. J. Allen and R. D. Geisert, unpublished).

Proteolysis of uterine IGFBPs may also occur through activation of latent forms of MMPs. Protease activity of the uterine flushings to IGFBP-3 was suppressed by the metal chelator, 1,10-phenanthroline, and EDTA. Deoxycycline, a broad-spectrum MMP inhibitor, inhibited degradation of IGFBP-2 and -3 (Golub et al., 1991). Wu et al. (1999) suggested that serine proteases activate latent MMP precursors, which then function to cleave IGFBP-3. Pig endometrium expresses genes for MMP-2 and MMP-9 (Menino et al., 1997) and gelatin zymography of uterine flushings produced bands of 72 and $92 \mathrm{kDa}$ corresponding to MMP-2 and MMP-9, respectively (Hillier et al., 1999). An increase in kallikrein activity within the uterine lumen on day 12 could activate these MMPs as tissue kallikrein activates the latent forms of MMP-2 and MMP-9 (Tschesche et al., 1989; Desrivieres et al., 1993).

In conclusion, the results of the present study indicate that loss of uterine luminal IGFBPs during the oestrous cycle and early pregnancy in pigs is probably regulated by progesterone. Loss of the IGFBPs in the uterine lumen on day 12 of the oestrous cycle or pregnancy results from increased activity of tissue kallikrein and activation of MMPs. Removal of the IGFBPs may allow an increase in IGF-I and -II bioavailability to stimulate conceptus steroidogenesis and endometrial development for the establishment of pregnancy.

The authors would like to thank S. Welty for the care and feeding of the animals used in the study, Monsanto Company (St Louis, MO) for the recombinant bovine IGF-II used for ligand blotting and radioimmunoassay, and Oklahoma State University Recombinant DNA/Protein Resource Facility for the use of the scanning densitometer. The authors would also to express their appreciation to M. Allen, A. Baue, M. Diederich, M. Looper and T. Pratt for their assistance with surgeries. This research was 
supported by NRICGP/USDA grant 98-35203-6224. The Director, Oklahoma Agriculture Experiment Station approved this article for publication.

\section{References}

Bhoola KD, Figueroa CD and Worthy K (1992) Bioregulation of kinins: kallikreins, kininogens, and kininases Pharmacological Reviews 44 $1-80$

Brigstock DR, Heap RB, Baker PJ and Brown KD (1990) Purification and characterization of heparin-binding growth factors from porcine uterus Biochemical Journal 266 273-282

Chan CS, Harvey MB and Clements JA (1999) Temporal and tissue-specific expression of kallikrein (Klk) genes and identification of a novel Klk messenger ribonucleic acid transcript during early development in the mouse Biology of Reproduction 61 621-628

Clements J (1997) The molecular biology of the kallikreins and their roles in inflammation. In The Kinin System pp 71-97 Ed. S Farmer. Academic Press, Great Britain

Cohen P, Graves HCB, Peehl DM, Kamarei M, Guidice LC and Rosenfeld RG (1992) Prostate-specific antigen (PSA) is an insulin-like growth factor binding protein-3 protease found in seminal plasma Journal of Clinical Endocrinology and Metabolism 75 1046-1053

Corthorn J and Valdes G (1994) Variations in uterine kallikrein during cycle and early pregnancy in the rat Biology of Reproduction 50 1261-1264

Corthorn J, Figueroa CD and Valdes G (1997) Estrogen and luminal stimulation of rat uterine kallikrein Biology of Reproduction 56 1432-1438

Desrivieres S, Lu H, Peyri N, Soria C, Legrand Y and Menashi S (1993) Activation of $92 \mathrm{kDa}$ type IV collagenase by tissue kallikrein Journal of Cell Physiology 157 587-593

Echternkamp SE, Spicer LE, Gregory KE, Canning SF and Hammond JM (1990) Concentrations of insulin-like growth factor-l in blood and ovarian fluid of cattle selected for twins Biology of Reproduction 43 $8-14$

Echternkamp SE, Howard HJ, Roberts AJ, Grizzle J and Wise T (1994) Relationship among concentrations of steroids, insulin-like growth factor-I, and insulin-like growth factor binding proteins in ovarian follicular fluid of beef cattle Biology of Reproduction 57 971-981

Elmlinger MW, Grund R, Buck M, Wollmann HA, Feist N, Weber MM, Speer CP and Ranke MB (1999) Limited proteolysis of the IGF binding protein-2 (IGFBP-2) by a specific protease activity in early breast milk Pediatric Research 46 76-81

Fazleabas AT, Geisert RD, Bazer FW and Roberts RM (1983) Relationship between release of plasminogen activator and estrogen by blastocysts and secretion of plasmin inhibitor by uterine endometrium in the pregnant pig Biology of Reproduction 29 225-238

Gauthier F, Moreau T, Gutman N, El Moujahed A and Brillard-Bourdet M (1992) Functional diversity of proteinases encoded by gene of the rat tissue kallikrein family Agents and Actions Supplements 38 42-50

Geisert RD and Yelich JV (1997) Regulation of conceptus development and attachment Journal of Reproduction and Fertility 52 133-149

Geisert RD, Renegar RH, Thatcher WW, Roberts RM and Bazer FW (1982) Establishment of pregnancy in the pig I. Interrelationships between periimplantation development of the pig blastocyst and the uterine endometrial secretions Biology of Reproduction 27 925-939

Geisert RD, Brenner RM, Moffatt RJ, Harney JP, Yellin T and Bazer FW (1993) Changes in estrogen receptor protein, mRNA expression and localization in the endometrium of cyclic and pregnant gilts Reproduction Fertility and Development 5 247-260

Geisert RD, Pratt T, Bazer FW, Mayes JS and Watson GH (1994) Immunocytochemical localization and changes in endometrial progestin receptor protein during the porcine oestrous cycle and early pregnancy Reproduction Fertility and Development 6 749-760

Geisert RD, Blair RM, Pratt T and Zavy MT (1997) Characterization and proteolytic activity of a cathepsin L-like polypeptide in endometrium and uterine flushings of cycling, pregnant and steroid-treated ovariectomized gilts Reproduction Fertility and Development 9 1-8
Golub LM, Ramamurthy NS, McNamara TF, Greenwald RA and Rifkin BR (1991) Tetracyclines inhibit connective tissue breakdown: new therapeutic implications for an old family of drugs Critical Reviews in Oral Biology and Medicine 2 297-322

Green ML, Simmen RCM and Simmen FA (1995) Developmental regulation of steroidogenic enzyme gene expression in the periimplantation porcine conceptus: a paracrine role for insulin-like growth factor-I Endocrinology 136 3961-3970

Gries LK, Geisert RD, Zavy MT, Garrett JE and Morgan GL (1989) Uterine alterations coincident with embryonic mortality in the gilt after exogenous estrogen administration Journal of Animal Science 67 276-284

Harding PA, Surveyor GA and Brigstock DR (1998) Characterization of pig connective tissue growth factor (CTGF) CDNA, mRNA and protein from uterine tissue DNA Sequence 8 385-930

Hillier M, Michel F, Grant M, Caballero S, and Simmen R (1999) Metalloprotease production by the peri-implantation pig endometrium Biology of Reproduction 60 (Supplement 1) 271 (Abstract)

Jones JI and Clemmons DR (1995) Insulin-like growth factors and their binding proteins: biological actions Endocrine Reviews 16 3-34

Ka H, Spencer TE, Johnson GA and Bazer FW (2000) Keratinocyte growth factor: expression by endometrial epithelia of the porcine uterus Biology of Reproduction 62 1772-1778

Ko Y, Choi I, Green ML, Simmen FA and Simmen RCM (1994) Transient expression of the cytochrome P450 aromatase gene in elongating porcine blastocysts is correlated with uterine insulin-like growth factor levels during peri-implantation development Molecular Reproduction and Development 37 1-11

Lee CY, Green ML, Simmen RCM and Simmen FA (1998) Proteolysis of insulin-like growth factor-binding proteins (IGFBPs) within the pig uterine lumen associated with peri-implantation conceptus development Journal of Reproduction and Fertility 112 369-377

Letcher R, Simmen RCM, Bazer FW and Simmen FA (1989) Insulin-like growth factor-I expression during early conceptus development in the pig Biology of Reproduction 41 1143-1151

Lowry OH, Rosebrough NJ, Farr AL and Randall RJ (1951) Protein measurements with the folin phenol reagent Journal of Biological Chemistry 193 265-271

Menino AR, Jr, Hogan A, Schultz GA, Novak S, Dixon W and Foxcroft GH (1997) Expression of proteinases and proteinase inhibitors during embryo-uterine contact in the pig Developmental Genetics 21 68-74

Murone C, Chai SY, Muller-Esterl W, Mendelsohn FAO and Clements J (1999) Localization of bradykinin $B_{2}$ receptors in the endometrium and myometrium of rat uterus and effects of estrogen and progesterone Endocrinology $1403372-3382$

Rechler MM (1993) Insulin-like growth factor binding proteins Vitamins and Hormones 47 1-114

Roberts RM and Bazer FW (1988) The functions of uterine secretions Journal of Reproduction and Fertility 82 875-892

Roberts RM, Bazer FW, Baldwin N and Pollard WE (1976) Progesterone induction of lysozyme and peptidase activities in the porcine uterus Archives of Biochemistry and Biophysics 177 499-507

Roberts RM, Trout WE, Mathialagan N, Stallings-Mann M and Ling P (1993) Uterine secretory activity and embryonic development. In Preimplantation Embryo Development pp 229-243 Ed. BD Bavister. Springer-Verlag, New York

SAS/STAT (1988) User's guide SAS Institute Inc, Cary

Simmen FA, Simmen RCM, Geisert RD, Martinat-Botte F, Bazer FW and Terqui M (1992) Differential expression, during the estrous cycle and pre- and postimplantation conceptus development, of messenger ribonucleic acids encoding components of the pig uterine insulin-like growth factor system Endocrinology 130 1547-1556

Simmen RCM, Green ML and Simmen FA (1995) IGF system in periimplantation uterus and embryonic development. In Molecular and Cellular Aspects of Preiimplantation Processes pp 185-204 Ed. SK Dey. Springer-Verlag, New York

Song S, Lee CY, Green ML, Chung CS, Simmen RCM and Simmen FA (1996) The unique endometrial expression and genomic organization of the porcine IGFBP-2 gene Molecular and Cellular Endocrinology 120 193-202 
Spicer LJ, Echternkamp SE, Wong EA, Hamilton DT and Vernon RK (1995) Serum hormones, follicular fluid steroids, insulin-like growth factors and their binding proteins, and ovarian IGF mRNA in sheep with different ovulation rates Journal of Animal Science 73 1152-1163

Spicer LJ, Alpizar E and Vernon RK (1999) Insulin-like growth factor I receptors in ovarian granulosa cells: effect of follicle size and hormones Molecular and Cellular Endocrinology 102 69-76

Trout WE, Hall JA, Stallings-Mann ML, Galvin JM, Anthony RV and Roberts RM (1992) Steroid regulation of the synthesis and secretion of retinolbinding protein by the uterus of the pig Endocrinology 130 2557-2564

Tschesche H, Michaelis J, Kohnert U, Fedrowitz OR (1989) Tissue kallikrein effectively activates latent matrix degrading metalloenzymes Advances in Experimental Medicine and Biology 247A 545-548

Tuo W, Harney JP and Bazer FW (1995) Colony-stimulating factor-1 in conceptus and uterine tissues in pigs Biology of Reproduction 53 133-142

Vallet JL, Christenson RK, Trout WF and Klemke HG (1998) Conceptus, progesterone, and breed effects on uterine protein secretion in swine Journal of Animal Science 76 2657-2670
Vonnahme KA, Malayer JR, Spivey HO, Ford SP, Clutter AC and Geisert RD (1999) Detection of kallikrein gene expression and enzymatic activity in porcine endometrium during the estrous cycle and early pregnancy Biology of Reproduction 61 1235-1241

Wu HB, Lee CY and Rechler MM (1999) Proteolysis of insulin-like growth factor binding protein-3 in serum from pregnant, non-pregnant and fetal rats by matrix metalloproteinases and serine proteases Hormone and Metabolic Research 31 186-191

Yousef GM, Chang A, Scorilas A and Diamandis EP (2000) Genomic organization of the human kallikrein gene family on chromosome 19q13.3-q13.4 Biochemical and Biophysical Research Communications $276125-133$

Received 15 September 2000.

First decision 10 November 2000

Accepted 22 December 2000. 